\title{
The Effects of Hydraulic Retention Time on Organic Loading Rate in Efficiency of Aerated Lagoons in Treating Rural Domestic Wastewater at El-Oued (South-East Algeria)
}

\author{
ZOBEIDI AMMAR*, BEBBA AHMED ABDELHAFID and DOUADI ALI \\ Laboratory of Valorization and Promotion of Sahara Resources (VPRS), University of \\ Kasdi Merbah Ouargla 30000, Algeria. \\ ${ }^{*}$ Corresponding author E-mail: zobeidi.aa@gmail.com \\ http://dx.doi.org/10.13005/ojc/330434
}

(Received: May 11, 2017; Accepted: June 09, 2017)

\begin{abstract}
This study detailed the effect hydraulic retention time on characteristics of the El-Oued aerated lagoons wastewater treatment plants (WWTPs), located in Southern East Algeria. The plant performance was evaluated through descriptive and statistical analysis of quantity and quality data of both raw wastewaters and treated effluent over a period of three years $(2013-2015)$. Therefore, the downstream values of BOD5, COD and TSS, are enough to achieve a final effluent that would meet the Algerian standards limit. The retention time is a function of the percent removal of organic load. The retention time may vary from 12 to 20 days as the optimum operating conditions the removal efficiencies $86.5 \%$ of BOD5, $78 \%$ of COD and TSS $85 \%$. Goodness of the model fit to the data was also evaluated through the relationship between the residuals and the model predicted values of BOD5r, CODr and TSSr. The advantage of this model is that it would allow a better process control.
\end{abstract}

Keywords: Aerated lagoon, El-Oued, Organic load, Retention time, Wastewater treatment plant.

\section{INTRODUCTION}

The region of El-Oued (south-east Algeria) had various water-related issues, discharging their highly-contaminated wastewater in the receiving environment without any treatment. This is an issue of growing concern because of side effects that pollutants can cause environmental and health problems. The choice of a wastewater treatment system in developing countries is subject to several criteria, the most important is the treatment efficiency of the system.

The wastewater treatment plant in aerated lagoons in the city of El-Oued she meets this criterion?

The purification of domestic wastewater system aerated lagoon remains among the most used in countries with hot climates arid to semi-arid 
processes. Since the late 2000, Algeria adopted for wastewater treatment in rural and urban centres aerated lagoon as the most suitable technical solution to the economic and climatic context ${ }^{1}$. Aerobic bacteria found in the aeration lagoon aerated lagoons consume oxygen dissolved in the medium for the oxidation of organic matter in the wastewater ${ }^{2-3}$. Oxygenation was, in the case of the aerated lagoon, provided mechanically by a surface aerator or air insufflations. This principle differs from activated sludge only by the absence of a recycling system for sludge or sludge extraction continuously. The energy consumption of the two streams is at equivalent capacity, comparable (1.8 to $2 \mathrm{~kW} / \mathrm{kg}$ BOD5 eliminated) ${ }^{4}$.

In our work, it is the characterization and quantification of some physicochemical parameters have provided a preliminary assessment of the degree of water pollution. Moreover, achieving optimal time stays through the Influence of hydraulic retention time (HRT) on the organic load of the effluent as a measure of the overall performance of a conventional WWTP under arid climatic conditions.

\section{MATERIALS AND METHODS}

\section{Treatment System Description}

The plant located $7 \mathrm{~km}$ to the SouthEast of El- Oued city. It is in operation since July
2009 to serve 246.000 populations. The capacity of the plant is to treat $33.000 \mathrm{~m}^{3} /$ day wastewater horizons for 2015, but the average current rate is $18.000-24.000 \mathrm{~m}^{3} /$ day. Each the first two is aerated lagoon; the 3rd is a polishing lagoon (Figure 1). Earthen berms form the wells of lagoons and a synthetic liner prevents sewage from entering groundwater. Details of the plant are shown in Table 1.

\section{Water Quality Analysis}

Study was carried for a period of three years (2013 - 2015) and samples were collected on weekly basis from raw wastewater and treated effluent. Physico-chemical characterization of wastewater was made according to French standard (AFNOR, 1997 $)^{5}$. Temperature and $\mathrm{pH}$ were analyzed with EUTECH Instruments $510 \mathrm{pH} / \mathrm{mV} /{ }^{\circ} \mathrm{C}$. Dissolved oxygen (DO) was determined by an oximeter (model WTW inoLab Oxi 730). Turbidity was measured by Turb 550 IR. The chemical oxygen demand (COD) was determined with the reactor digestion using a Spectrophotometer type WTW Photolab spectral analyzer (AFNOR T90-101). The 5-day biological oxygen demand (BOD5) was determined by the manometric method with a respirometer (BSBcontrolled Model OxiTop WTW) (AFNOR T90 105). The suspended solids (TSS) were determined by filtration and drying at $110^{\circ} \mathrm{C}$ (AFNOR T90-105) ${ }^{6}$.

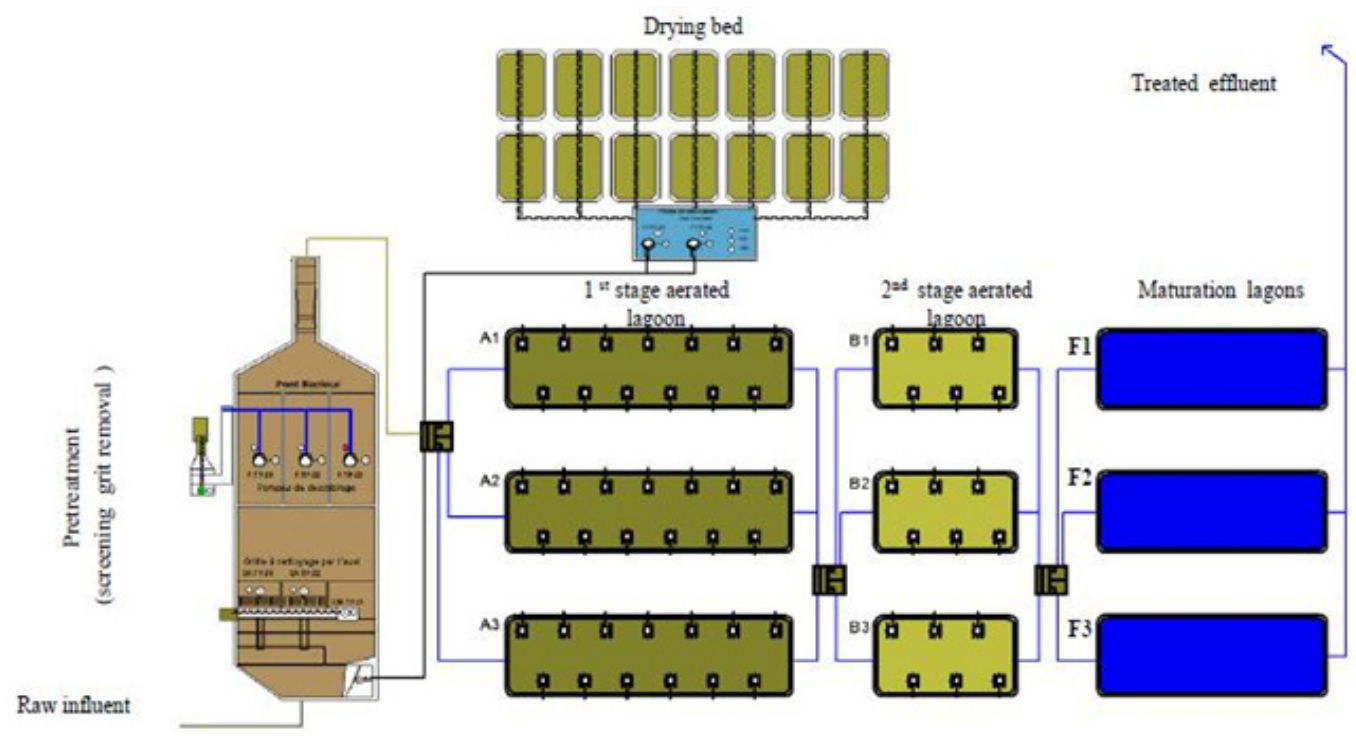

Fig.1: Localization and schematic representation of El-Oued wastewater treatment plant. 


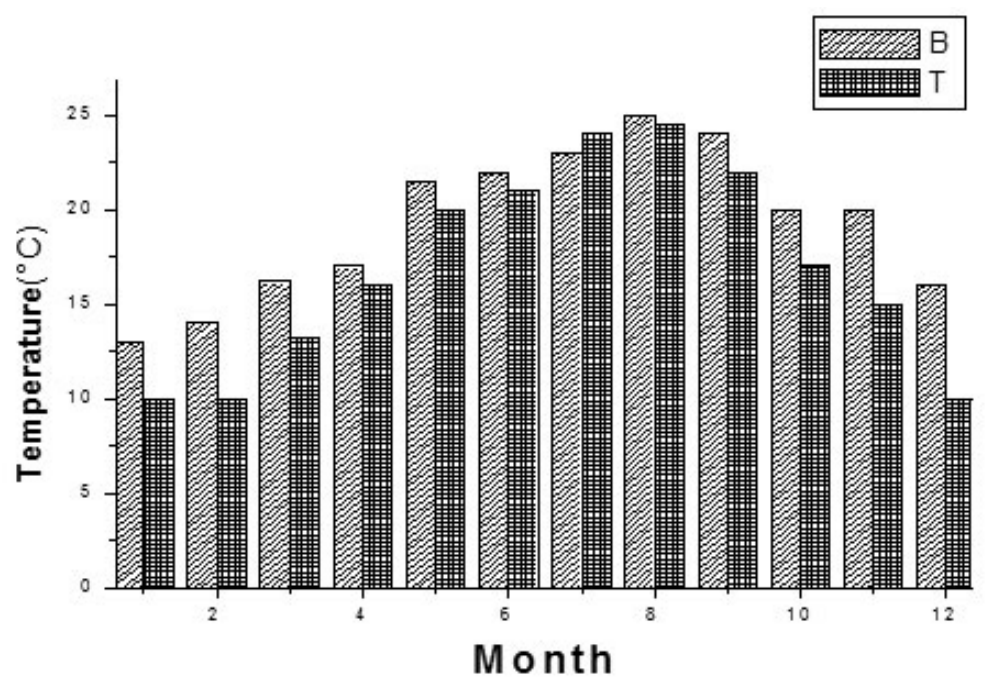

Fig. 2: Evolution of Temperature in raw wastewater and treated effluent

Table1: Design description of the aerated lagoons in El-Oued

\begin{tabular}{llll}
\hline Lagons & $\begin{array}{l}\text { Aerated } \\
\text { (A1, A2, A3) }\end{array}$ & $\begin{array}{l}\text { Aerated } \\
\text { (B1, B2, B3) }\end{array}$ & $\begin{array}{l}\text { Maturation } \\
\text { (F1, F2, F3) }\end{array}$ \\
\hline $\begin{array}{l}\text { Volume }\left(\mathrm{m}^{3}\right) \\
\text { of each } \\
\text { Dimensions }\end{array}$ & 199413 & 133107 & 99810 \\
$\begin{array}{l}\text { (m) } \\
\text { of each }\end{array}$ & $91 \times 232,6 \times 3,5$ & $92,1 \times 194,6 \times 2,5$ & $91,6 \times 245,3 \times 1,5$ \\
$\begin{array}{l}\text { No. } \\
\text { Aerators } \\
\text { of each }\end{array}$ & 39 & 18 & 0 \\
\hline
\end{tabular}

Removal efficiency of studied plant was determined as the percentage of decrease in influent with respect to effluent for each parameter measured.

\section{Statistical Analyses}

All statistical analysis was performed using the XLSTAT (version 7.5.2) ${ }^{7}$. Simple correlations were used to determine if significant relationships existed between parameters concentrations in raw wastewater (dependent variables) and treated effluent (independent variables). Stepwise multiple regressions were used to determine which parameters were significant in forecasting the dependent variables (biological oxygen demand removal (BOD5r), chemical oxygen demand removal (CODr) and suspending solids removal
(SSr)). Once the independent variables, significantly associated with dependent variables, the coefficients of determination $\left(R^{2}\right)$ for regression models were calculated. The relative contribution of each independent variable to the variation of dependent variables removal efficiencies in selected models was determined.

\section{RESULTS AND DISCUSSION}

\section{Plant Operation}

During the present study the influent raw sewage was an average of $18,700 \mathrm{~m}^{3} /$ day, ranged from 18,000 to $24,000 \mathrm{~m}^{3} /$ day. The range of the Hydraulic retention time was (12-20) days. During this period, two aerated lagoons (A1, A2) in first stage, in second stage one aerated lagoon (B1- B2) 
and mostly one polishing lagoon (P1 or P2) were in service.

\section{In-Situ Field Conditions}

The major parameters that influence the removal mechanisms for organic matter in constructed wetlands are temperature, turbidity, dissolved oxygen (DO) and $\mathrm{pH}^{5}$. This is because organisms present in biological wastewater treatments are sensitive to these parameters.

During the investigation study, the average values of wastewater temperature are $19.31{ }^{\circ} \mathrm{C}$, $13^{\circ} \mathrm{C}$ and $25^{\circ} \mathrm{C}$, respectively, and this were in the range with the meteorological means of $16.89^{\circ} \mathrm{C}$,
$10{ }^{\circ} \mathrm{C}$ and 24.5 (Figure. 2). they are similar to the air temperature; the temperatures of the final effluent are still lower than those recorded in the influent these values are based on the sampling time and the weather.

The turbidity values stored in the wastewater before treatment average values are 306 NTU, 202 NTU and 375 NTU. Regarding the treated water, there is a net reduction of this parameter whose values are within a range that is 13 NTU to 69 NTU, the average values are 33.73 NTU (Figure 3), these values are still lower than the Algerian standards rejection $(50 \mathrm{NTU})^{8}$.

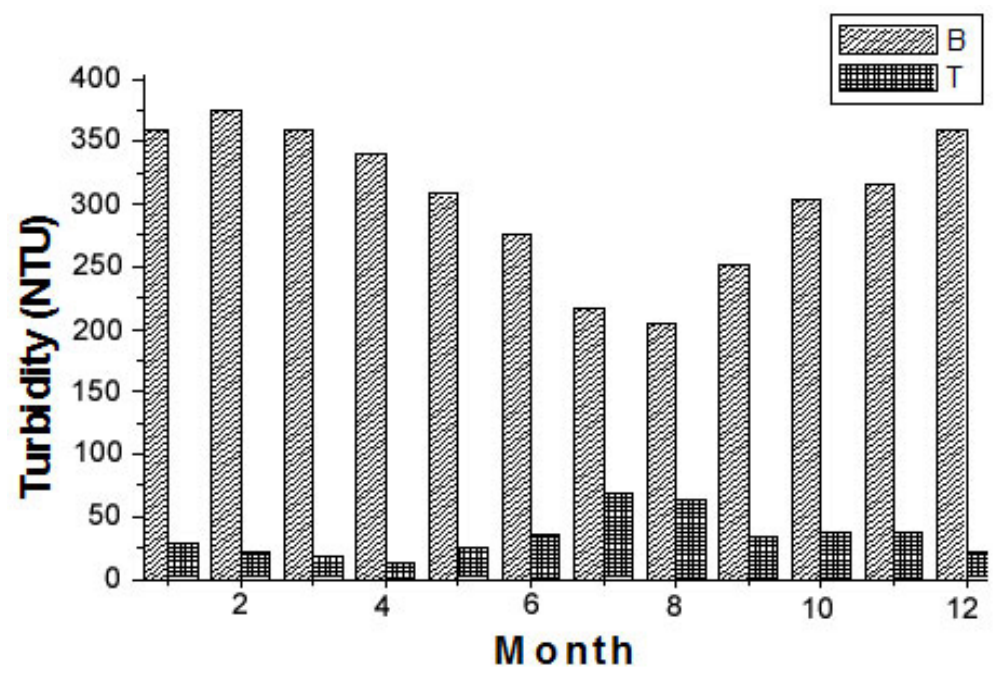

Fig. 3: Evolution of turbidity in raw wastewater and treated effluent

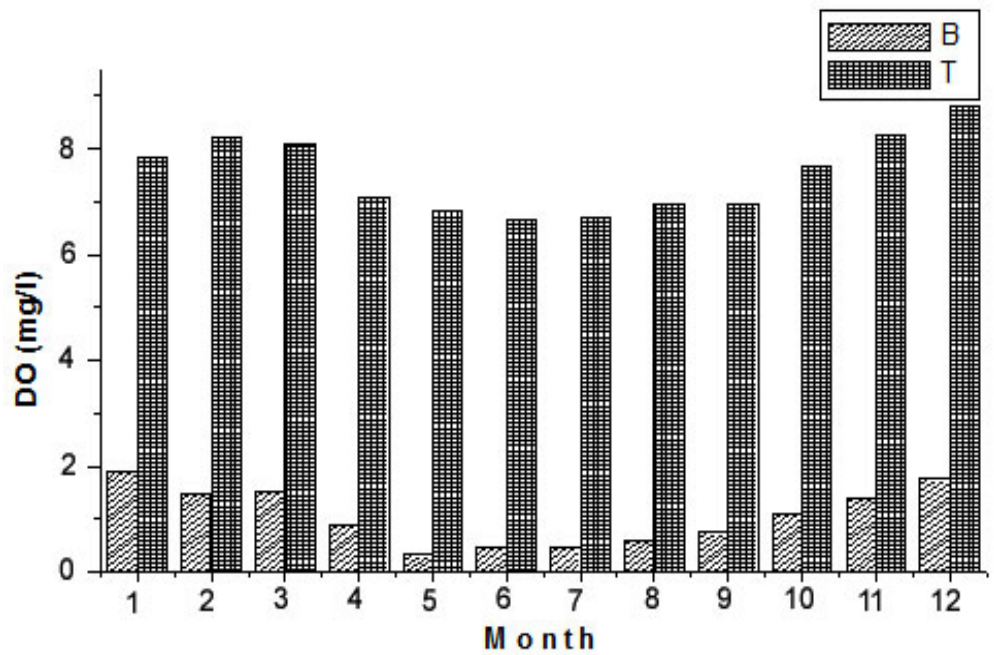

Fig. 4: Evolution of DO in raw wastewater and treated effluent 
Then we see that in general a good return for their variation purified water under the effect of the temperature rise that promotes excessive algae growth, thus increasing the turbidity removal is greater in hot season $(87.82 \%)$ in the cold season (93.52\%).

The variation of monthly average $\mathrm{DO}$ values in raw wastewater varied between 2013 and 2015 are $1.05 \mathrm{mg} / \mathrm{L}, 0.32 \mathrm{mg} / \mathrm{L}$ and $1.91 \mathrm{mg} / \mathrm{L}$ (Figure 4), low characterizing a wastewater inlet rich in dissolved organic and inorganic matter and disruption of air exchanges in interface due to the presence of fats, detergents ... etc. $)^{9}$.
Regarding in treated effluent, DO levels recorded at the outlet are substantially greater than those of the entrance, the average values close to $7.50 \mathrm{mg} / \mathrm{L}$, ranging of $6.65 \mathrm{mg} / \mathrm{L}$ to $8.81 \mathrm{mg} / \mathrm{L}$, this is due to ventilation of the water level of the basin aeration related surface aerators, necessary to develop the aerobic microorganisms ensuring the oxidation of organic matter, which leads to a good biological wastewater treatment. This value is almost invariable regardless of the period, but changes depending on the incoming organic filler ${ }^{10}$.

This Regarding in treated effluent, DO levels recorded at the outlet are substantially greater

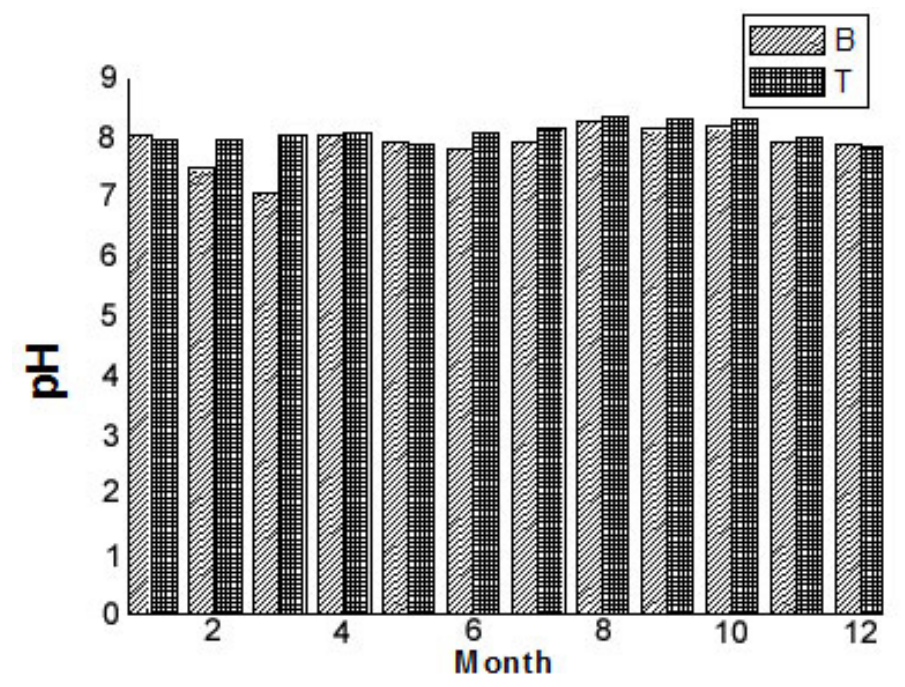

Fig.5: Evolution of $\mathrm{pH}$ in raw wastewater and treated effluent

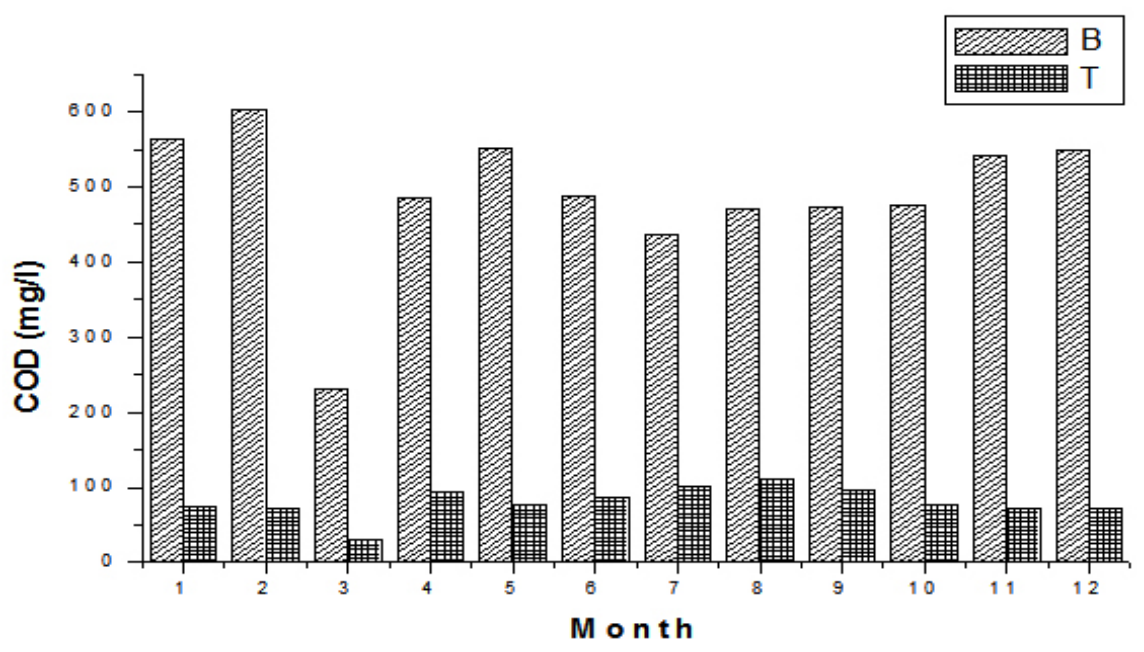

Fig. 6: Evolution of COD in raw wastewater and treated effluent 
than those of the entrance, the average values close to $7.50 \mathrm{mg} / \mathrm{L}$, ranging of $6.65 \mathrm{mg} / \mathrm{L}$ to $8.81 \mathrm{mg} / \mathrm{L}$, this is due to ventilation of the water level of the basin aeration related surface aerators, necessary to develop the aerobic microorganisms ensuring the oxidation of organic matter, which leads to a good biological wastewater treatment. This value is almost invariable regardless of the period, but changes depending on the incoming organic filler ${ }^{10}$.

The $\mathrm{pH}$ is a fundamental factor for water quality which mainly depends upon a variety of chemical factors, e.g., dissolved gases, organic acids, humic fractions and inorganic salts. The decomposition of organic fractions of wastewater, mainly by microbes in water, produces some acidic species of mineralized organic materials (CO2, ammonia, NO3- and organic acids) which plays an important role in shifting of $\mathrm{pH}$ scale of treated water ${ }^{11}$.

During the study period (2013 - 2015), the treated effluent $\mathrm{pH}$ is mostly higher than that for the raw wastewater (Fig. 3). Measured $\mathrm{pH}$ values were consistently increased by between 0.53 and 0.98 units giving relatively stable monthly average $\mathrm{pH}$ effluent between 7.89 and 8.08. These results are consistent with those reported in the literature. According, Sevrin Reyssac et al., ${ }^{12}$, the alkaline $\mathrm{pH}$ and moderate temperature environment are ideal conditions for the proliferation of microorganisms which establish a perfect biological stability, allowing the degradation of organic matter resulting in the decontamination of water. This increase can be explained by an intense microbial activity in the activation lagoon where oxygen consumption therefore importance of a significant release of $\mathrm{CO}_{2}{ }^{10}$.

\section{Organic matter}

The organic matter, expressed as BOD, COD and TSS, is decomposed by aerobic and anaerobic microbial processes and also by physical processes, such as sedimentation and filtration.

The variation of monthly average COD values, in treated effluent showed a trend which is not consistent with that of raw wastewaters (Figure 6). As regards to the results of the statistical analysis, lack correlation between raw wastewater and treated effluent $\left(R^{2}=0.75\right)$ ensures the dependence of downstream conditions on the other factors than upstream conditions. This fact could be assigned to an irregular work of aerators functioning. During the studied period, the monthly COD values was $80.86 \mathrm{mg} \mathrm{O}_{2} / \mathrm{L}$ exceeding Algerian standards (90 mg O2/L) confirm a chemical disequilibrium of the system ${ }^{8}$.

Average BOD5 values in raw wastewater also varied between 2013 and 2015 (Figure 7). Its general trend is not similar to that of COD. It is characterized by a decreasing rate from 222.90 to $274.31 \mathrm{mg} \mathrm{O2} / \mathrm{L}$. Moreover, it is important to note that over the period, the representative BOD daily average

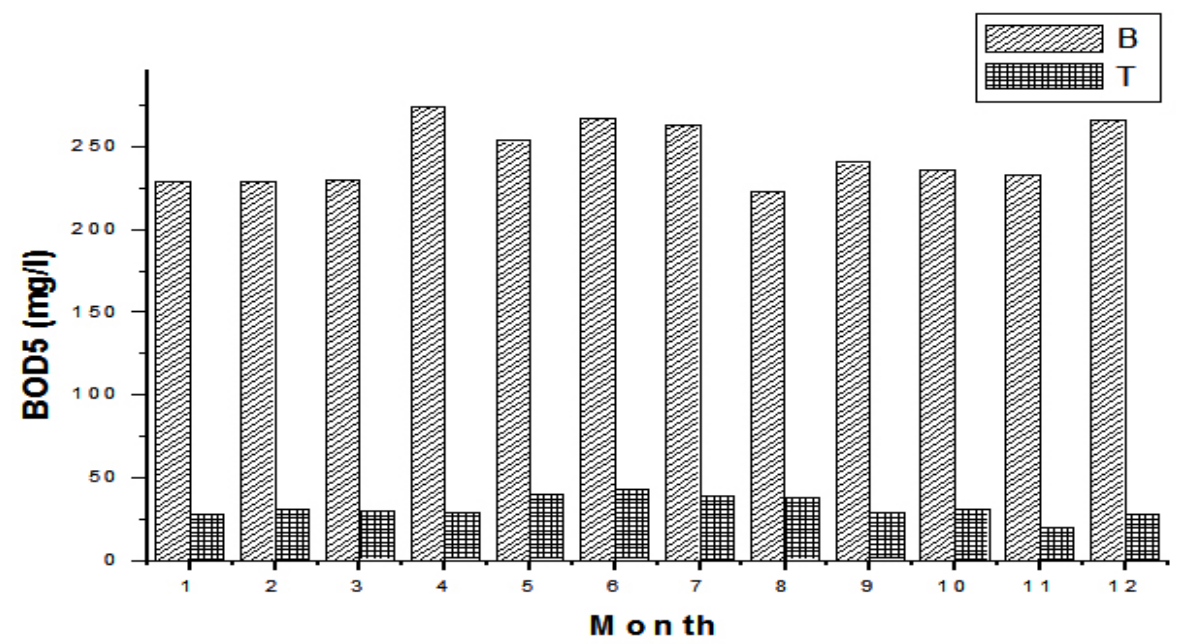

Fig. 7: Evolution of BOD5 in raw wastewater and treated effluent 
load was shown to be lower than the recommended value of $4648.82 \mathrm{Kg}$ per day. As regards to the results of the statistical analysis, lack correlation between raw wastewater and treated effluent $\left(R^{2}=0.40\right)$.

In treated effluent, the monthly average BOD5 values showed $32 \mathrm{mg} \mathrm{O}_{2} / \mathrm{L}$, in general, the same decreasing trend as in raw wastewater. The decreasing rate of values is much more important in treated effluents. According Bliefert and Perraud ${ }^{13}$, the values of COD and BOD5 treated water are typical municipal water after biological treatment. Over the studied period, despite the conformity of upstream values to the recommendations, the downstream values are relatively low than Algerian standards $\left(40 \mathrm{mg} \mathrm{O}_{2} / \mathrm{L}\right)^{8}$.

According to Metcalf \& Eddy ${ }^{14}$, the ratio between COD and BOD5 can characterize the nature of the effluent entering the WWTPS 01 Kouinine, which may be domestic or industrial. It can be clearly seen that wastewater is readily biodegradable for all incoming wastewater, and is on average between $1.98<2.5$. This result confirms the absence of industrial waste connected to the domestic sewerage network.

Indeed, it averages lead to the conclusion that this is a gross impact readily biodegradable.

Over the period 2013 - 2015, the evolution of monthly TSS concentrations in raw wastewater showed similar trend to that of BOD5. It is characterized by two evolution phases: the monthly average values around $256 \mathrm{mg} / \mathrm{L}$ and varied from $202 \mathrm{mg} / \mathrm{L}$ to $303 \mathrm{mg} / \mathrm{L}$. TSS concentrations in treated effluent varied from 12.5 to 59.9 and the mean value was $36.5 \mathrm{mg} / \mathrm{L}$ (Figure 8). Statistical analysis shows also lack linearity $\left(R^{2}=0.39\right)$ between raw wastewater and treated effluent.

It is interesting to note that there is reduction of all parameters characterizing the organic load (COD, BOD5 and TSS). The overall removal efficiency of organic load in the system by 15 days' retention $86.5 \%$ of BOD5, time $78 \%$ of COD and $85 \%$ of TSS.

The statistical analysis showed a very strong (- ve) correlation between retention time and BOD5, TSS and COD ( $r=0.92,0.98,0.64$ and 0.41; $p<0.05)$, respectively.

\section{Multiple regression and predictive models}

A linear multivariate regression model estimates the behavior of a dependent variable based on several independent variables, provided that a linear relation exists between the dependent variable and the rest of parameters. The result of this analysis is a linear equation $(y=a x 1+$ $\mathrm{bx} 2+\mathrm{cx} 3+\ldots+\mathrm{d})$. In the present work, the forward stepwise method was particularly conducted to test the relationship between each of the changes of

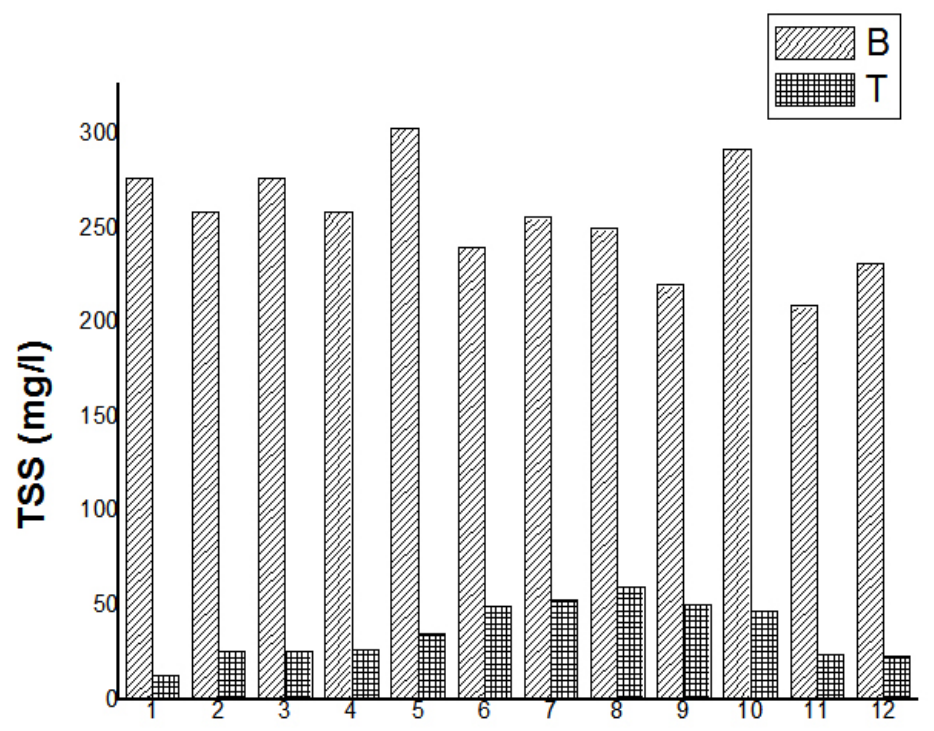

Fig. 8: Evolution of TSS in raw wastewater and treated effluent 
Table 2: Predictive models and evaluation of fit

\begin{tabular}{|c|c|c|c|}
\hline $\begin{array}{l}\text { Dependant } \\
\text { variables }\end{array}$ & $\begin{array}{l}\text { Predictor independent } \\
\text { variables }\end{array}$ & Cont & $\mathbf{R}^{2}$ \\
\hline $\mathrm{BOD}_{5} \mathrm{r}$ & $\begin{array}{l}\mathrm{DBO} 5(\mathrm{~T})=0,101 \mathrm{DBO} 5(\mathrm{~W})-4,151 \\
\text { HRT }\end{array}$ & 83,20 & 0.86 \\
\hline CODr & $\begin{array}{l}\mathrm{DCO}(\mathrm{T})=0,782 \mathrm{DCO}(\mathrm{W})-50,24 \\
\mathrm{HRT}\end{array}$ & 542,31 & 0.78 \\
\hline TSSr & $\begin{array}{l}\text { TSS }(T)=0,1074 \text { TSS }(W)-3,905 \\
\text { HRT }\end{array}$ & 89,16 & 0.85 \\
\hline
\end{tabular}

BOD5, COD and TSS removal efficiencies and other variables. The independent variables included in the model were the retention time, COD $w / B O D 5 w$ and rain water, as well as the influent and the effluent loading rates of COD, BOD5 and TSS. For each of the variables entered in the model, the forward selection calculates the $\mathrm{F}$ statistic reflecting the contribution of the test variable to the model. For the entrance of the variables into the model, a rather liberal significance level $(p=0.5)$ has been selected to ovoid the elimination of the significant factor. This procedure calculates the coefficient of determination $\left(R^{2}\right)$ for all models.

Table 2 depict predictive models constructed for predicting removal efficiencies of BOD5, COD and TSS, and predicted retention time values

Where; r: removal efficiency; w: raw wastewater; t: treated effluent, HRT Hydraulic Retention Time

\section{CONCLUSION}

The results presented show that the aerated lagoon process is effective in the treatment of urban waste water under the climatic conditions of the city of El-Oued located in Southern East Algeria. The plant performance was evaluated through descriptive and statistical analysis of quantity and quality data of both raw wastewaters and treated effluent over a period of three years $(2013-2015)$.
Therefore, the downstream values of BOD5, COD and TSS, are enough to achieve a final effluent that would meet the Algerian standards limit. The retention time is a function of the percent removal of organic load. The retention time may vary from 12 to 20 days as the optimum operating conditions the removal efficiencies $86.5 \%$ of BOD5, $78 \%$ of COD and TSS $85 \%$. Goodness of the model fit to the data was also evaluated through the relationship between the retention time, raw wastewater and the model predicted values of BOD5t, CODt and TSSt. The advantage of this model is that it would allow a better process control.

\section{Nomenclature}

BOD5: The 5-day Biochemical Oxygen Demand COD: Chemical Oxygen Demand DO: Dissolved oxygen

HRT: Hydraulic Retention Time

ISO: International Organization for Standardization NTU: Nephelometric Turbidity Unit

TSS: Total Suspended Solids WWTPs: Wastewater treatment Pants

\section{ACKNOWLEDGMENT}

The author is thankful to MEHIDA Hicham and ABBANE Fathi the head of wastewater treatment plant in aerated lagoons Kouinine, for providing laboratory facilities.

\section{REFERENCES}

1. Duncan, M. In sewage treatement in hot climates: John Wiley \& Sons. 1980,48,49.
2. Francis, E. Le traitement des eaux usées dans les industries agroalimentaires, Rev. Nou. Sci. 
Tech.1989, 2(7), 83-89.

3. Malina, J. F.; Yousef, Y. A. The fate of Coliform organisms in waste stabilization ponds, J. Wat. Pollut Control Fed.1964, 36, 14321442.

4. Agence de I'Eau Seine-Normandie. Guides des procédés épuratoires intensifs proposés aux petites collectivités. 2001, ISBN 92-8941690-4, 20.

5. Rodier, J. ; Legube, B. ; Meriet N. Analyse de l'eau: eaux naturelles, eaux résiduaires, eau de mer. 2009, 9 ème édition, 111-300,

6. AFNOR, Association Française de Normalisation. Recueil des normes françaises : qualité de l'eau, Environnement, Paris, 1994.

7. STATIT-CF Services des études statistiques de I'Institut Technique des Céréales et Fourrages (I.T.C.F). Boigneville.1987.

8. Arrête interministériel.; Les spécifications des eaux usées épurées utilisées à des fins d'irrigation. Journal officiel $\mathrm{N}^{\circ} 41$ de la république algérienne démocratique et populaire. 2012.

9. Hazourli, S. ; Boudiba, L. ; ZIATI, M ; Caractérisation de la pollution des eaux résiduaires de la zone industrielle- d'EI Hadjar, Annaba. Larhyss Journal. 2007, ISSN 1112-3680, 2007., 06.,45-55.

10. Zobeidi, A.; Bebba, A.A.; seasonal variations of physical, chemical parameters in a wastewater treatment plant by aerated lagoons at southern-east of Algeria, RJPBCS. 2015, 6 (3), 1097.

11. Belhaja, D.; Jaabirib, I.; Turkic, N.; Azrid, C.; Kallele, M .;Ayadif, $\mathrm{H}$, Descriptive and multivariable analysis of the water parameters quality of Sfax sewage treatment plant after rehabilitation, IOSR Journal of Computer Engineering. 2014,16,81-91.

12. Sevrin-Reyssac, J.; De La Noue, J.; Proulx, D. Le recyclage du lisier de porc par lagunage.1995, Edition Technique et Documentation Lavoisier, 118.

13. Briefer, C.; Perraud, R. Chimie de l'environnement:Air, Eau, Sols, Déchets. 2001, Edition de Boeck, 317 - 477.

14. Franklin Louis Burton, H. David Stensel, Metcalf \& Eddy, Inc. Wastewater engineering: Treatment and Reuse..4ème Edition Mc Graw-Hill New York, 2003.,24-32. 